\title{
Vickermania gen. nov., trypanosomatids that use two joined flagella to resist midgut peristaltic flow within the fly host
}

Alexei Y. Kostygov ${ }^{1,2^{*}}$ D, Alexander O. Frolov², Marina N. Malysheva ${ }^{2}$, Anna I. Ganyukova ${ }^{2}$, Lyudmila V. Chistyakova ${ }^{2}$, Daria Tashyreva ${ }^{3}$, Martina Tesařová3 ${ }^{3}$ Viktoria V. Spodareva1,2, Jana Režnarová', Diego H. Macedo ${ }^{1}$, Anzhelika Butenko ${ }^{1,3}$, Claudia M. d'Avila-Levy', Julius Lukešs ${ }^{3,5}$ and Vyacheslav Yurchenko ${ }^{1,6}$

\begin{abstract}
Background: The family Trypanosomatidae encompasses parasitic flagellates, some of which cause serious vectortransmitted diseases of humans and domestic animals. However, insect-restricted parasites represent the ancestral and most diverse group within the family. They display a range of unusual features and their study can provide insights into the biology of human pathogens. Here we describe Vickermania, a new genus of fly midgut-dwelling parasites that bear two flagella in contrast to other trypanosomatids, which are unambiguously uniflagellate.

Results: Vickermania has an odd cell cycle, in which shortly after the division the uniflagellate cell starts growing a new flagellum attached to the old one and preserves their contact until the late cytokinesis. The flagella connect to each other throughout their whole length and carry a peculiar seizing structure with a paddle-like apex and two lateral extensions at their tip. In contrast to typical trypanosomatids, which attach to the insect host's intestinal wall, Vickermania is separated from it by a continuous peritrophic membrane and resides freely in the fly midgut lumen.

Conclusions: We propose that Vickermania developed a survival strategy that relies on constant movement preventing discharge from the host gut due to intestinal peristalsis. Since these parasites cannot attach to the midgut wall, they were forced to shorten the period of impaired motility when two separate flagella in dividing cells interfere with each other. The connection between the flagella ensures their coordinate movement until the separation of the daughter cells. We propose that Trypanosoma brucei, a severe human pathogen, during its development in the tsetse fly midgut faces the same conditions and follows the same strategy as Vickermania by employing an analogous adaptation, the flagellar connector.
\end{abstract}

Keywords: Herpetomonas muscarum ingenoplastis, Cell cycle, Flagella connector, Trypanosoma brucei

\footnotetext{
* Correspondence: kostygov@gmail.com

'Life Science Research Centre, Faculty of Science, University of Ostrava, Chittussiho 10, 71000 Ostrava, Czechia

${ }^{2}$ Zoological Institute of the Russian Academy of Sciences, St. Petersburg 199034, Russia

Full list of author information is available at the end of the article
}

(c) The Author(s). 2020 Open Access This article is licensed under a Creative Commons Attribution 4.0 International License, which permits use, sharing, adaptation, distribution and reproduction in any medium or format, as long as you give appropriate credit to the original author(s) and the source, provide a link to the Creative Commons licence, and indicate if changes were made. The images or other third party material in this article are included in the article's Creative Commons. licence, unless indicated otherwise in a credit line to the material. If material is not included in the article's Creative Commons licence and your intended use is not permitted by statutory regulation or exceeds the permitted use, you will need to obtain permission directly from the copyright holder. To view a copy of this licence, visit http://creativecommons.org/licenses/by/4.0/ The Creative Commons Public Domain Dedication waiver (http://creativecommons.org/publicdomain/zero/1.0/) applies to the data made available in this article, unless otherwise stated in a credit line to the data. 


\section{Background}

Flagellates of the family Trypanosomatidae (Euglenozoa: Kinetoplastea) are obligatory parasites inhabiting vertebrates, arthropods, leeches, and plants [1,2]. Since numerous dixenous trypanosomatids, i.e., those alternating between vertebrate and invertebrate hosts, cause diseases in humans and domestic animals, they were given most attention [3-5]. However, the insect-restricted monoxenous trypanosomatids are ancestral and more diverse, with some of their representatives having unusual features, such as an idiosyncratic genetic code [6], bacterial endosymbionts [7-9], and novel viruses [10, 11].

For a long time, the classification of monoxenous trypanosomatids was based solely on morphology, with each genus characterized by a predominant and/or unique morphotype $[12,13]$. Because of the deficit of morphological features, species delimitation was even more precarious. The situation was ameliorated by sequence-based approaches that provided a significantly higher resolution [14] and allowed testing old morphological descriptions in the molecular phylogenetic framework [15].

Herpetomonas muscarum is the first named monoxenous trypanosomatid, originally reported in 1856 from the housefly Musca domestica in the USA [16]. Later, flagellates from about 30 dipteran species of eight families, sampled around the world, were classified as $H$. muscarum $[1,17]$. The first detailed characterization of this species pointed to the presence of two united flagella [18], a peculiar feature proposed to be diagnostic for the genus Herpetomonas. However, many authors criticized this idea, arguing that biflagellate cells represented nothing but dividing forms, and, therefore, synonymized Herpetomonas with Leptomonas and even Leishmania [19-23]. Afterwards, the proposal to distinguish Herpetomonas from Leptomonas based on the presence of a particular morphotype, now termed opisthomastigote [12], became widely adopted [24, 25].

The biflagellate cells were forgotten for over 50 years and brought to light again only in 1971, when two cultures of morphologically distinct trypanosomatids were isolated from flies. These were described as two subspecies of Herpetomonas muscarum: H. m. muscarum with predominantly uniflagellate cells possessing a narrow rod-shaped kinetoplast and $H . m$. ingenoplastis with mainly biflagellate cells bearing a larger teardrop-shaped kinetoplast [26]. Later, comparative studies of these two subspecies revealed that they also substantially differ in proliferation rates, metabolism, and sizes of the kinetoplast DNA (kDNA) circles [27-31].

However, little attention was paid to the phenomenon of double flagella, the most striking feature of $H . m$. ingenoplastis. All other known trypanosomatids are uniflagellate and possess second flagellum only for a short period, during cell division [32, 33]. Outside trypanosomatids, all motile kinetoplastids have two flagella, but those are heterodynamic: one is oriented anteriorly and the other posteriorly [34]. In this study, we have performed a morphological and molecular re-description of $H$. $m$. ingenoplastis and a newly isolated related species, and studied their development both in culture and in experimentally infected flies. Our results demonstrate that both species, now assigned to a new trypanosomatid genus Vickermania, have a very unusual kinetoplast and suggest that they became biflagellate to adapt to life in the midgut of flies.

\section{Results}

\section{Light microscopy and cultivation}

Light microscopic examination of the axenic cultures CP021 (replica of Herpetomonas muscarum ingenoplastis type culture) and S13 (newly isolated from an ensign fly) as well as the xenic culture Trypanomatidae sp. F72 (newly isolated from a green bottle fly) revealed the presence of a single morphotype-promastigotes (Fig. 1, Additional file 1: Fig. S1). In all studied strains, their size was similar (Additional file 2: Table S1) and did not change during cultivation, although the maximal lengths of cell and flagella in S13 exceeded those in others. In all cultures, some promastigotes appeared uniflagellate, although their flagellum was often conspicuously thicker in the proximal part (Fig. 1a); others had two completely separate flagella (Fig. 1b) with a noticeable thickening at their tip (Fig. 1a, f). In addition, there were many intermediate variants with flagella being separated only until a certain point (Fig. 1c-f), sometimes only inside the flagellar pocket.

The examination of the smear made from the naturally infected fly intestine, which served as a source of the S13 culture (sample S13-gut), revealed that the majority of cells were strikingly different from those in the culture. They had epimastigote morphology and a conspicuously shorter free flagellum, no longer than half of the cell body (Fig. 1g).

The cultures CP021 and S13 showed similar growth dynamics with approximately the same maximum density $\left(6-9 \times 10^{6}\right.$ cells $\left./ \mathrm{ml}\right)$ reached on day 5 , followed by a rapid decline (Additional file 3: Fig. S2). The proportion of unambiguously biflagellate cells (i.e., those with wellseparated flagella), as estimated for CP021, was minimal during the intense growth phase $(<5 \%)$ and increased to $17-35 \%$ in old cultures (day 9).

\section{Molecular phylogenetic analyses}

The comparison of the newly obtained $18 \mathrm{~S}$ rRNA gene sequences revealed that they belong to three separate species. The first of them included indistinguishable CP021 and F72, the second-S13 (97.13\% identical to 


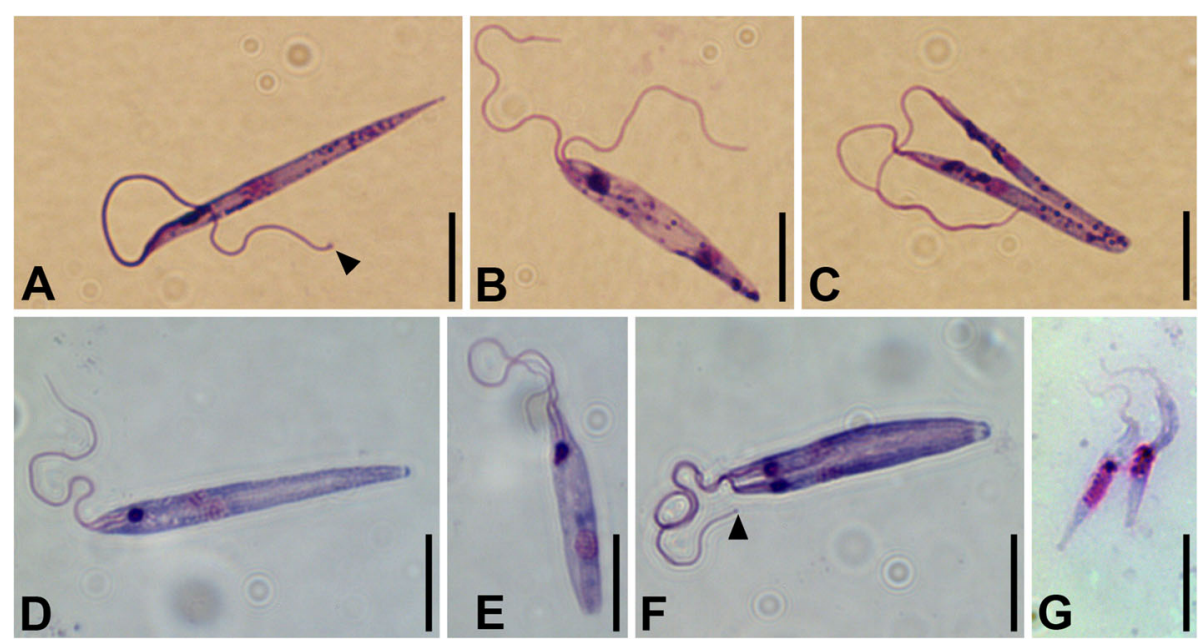

Fig. 1 Cells on Giemsa-stained smears. a-c Culture CP021. $\mathbf{d}-\mathbf{f}$ Culture S13. g Epimastigotes in S13-gut sample. Arrowhead points to the terminal thickening of the flagellum. Scale bars are $10 \mu \mathrm{m}$

the first), while the third one-from the naturally infected fly intestine (sample S13-gut) - shared $94.05 \%$ and 93.13\% identity with the above two species, respectively.

On the inferred 18S rRNA gene tree (Fig. 2a), all three species fell into a clade that had maximal support on both ML and Bayesian trees and consisted of two subclades. The first one includes S13-gut sample along with the isolates 6.7, G42 and D44-1 from Drosophila ananassae, the assassin bug Nagusta cf. punctaticollis, and feces of a great ape, respectively [35-37]. The second subclade, with a high posterior probability and a moderate bootstrap support, contained CP021 and S13, as well as the isolates MCC-01 from an unidentified fly, MCC02 and MCC-03 from Drosophila sp., and GMO-05 from Musca sp. [38, 39]. Although both applied phylogenetic methods placed Wallacemonas as a sister group to the clade under discussion, and Jaenimonas drosophilae as the next closest neighbor, these relationships were poorly supported. The removal of either of these two genera from the dataset resulted in a slight increase of the bootstrap supports (to 55-61\%) and more significant rise of the posterior probabilities (to 0.97-0.99), supporting the association of the clade under question with the remaining taxon (data not shown).

The only other well-sampled marker that has been widely used for inference of trypanosomatid phylogeny is the glycosomal glyceraldehyde-3-phosphate dehydrogenase (gGAPDH) gene [40]. However, it was shown to produce artifacts, due to the compositional bias in nucleotide sequences $[8,9,41,42]$. By using the amino acid sequences of gGAPDH, we attempted to benefit from the large available dataset, while decreasing the risk of artifacts (Additional file 4: Fig. S3). This analysis recovered genuslevel clades with moderate-to-maximal supports, but virtually failed at a higher level: Strigomonadinae appeared paraphyletic, while Phytomonadinae, though monophyletic by ML, had a very low bootstrap support. Nevertheless, the gGAPDH sequences of CP021 and S13 formed a clade with maximal support, which also includes an undescribed parasite of Drosophila obscura and D. tristis [43]. Thus, CP021 and S13 belong to a lineage without a taxonomic name. Based on their separate phylogenetic position and distinct morphology, we propose to accommodate them in a newly erected genus Vickermania (see the "Taxonomic summary" section for details).

Given the availability of the recently published genomic sequence of the isolate CP021 [44], we decided to take advantage of the high-resolution power inherent to phylogenomic analysis. The ML and Bayesian trees inferred using concatenated sequences of 160 proteins invariantly placed Vickermania as an independent lineage branching off the trypanosomatid stem right after Blechomonadinae and thereby being sister to the assemblage of the subfamilies Leishmaniinae, Strigomonadinae, and Phytomonadinae (Fig. 2b). Regrettably, the lack of genomic data for Wallacemonas and Jaenimonas did not allow testing whether any of these two genera is related to Vickermania as suggested by the analysis of the $18 \mathrm{~S}$ rRNA gene.

\section{Transmission electron microscopy}

At the ultrastructural level, CP021 and S13 are generally similar to most trypanosomatids studied to date. Flagella with basal bodies, kinetoplast, nucleus, and Golgi apparatus were situated in the anterior part of the cell (Figs. 3a and $4 \mathrm{a})$. The flagellar pocket was $3-4 \mu \mathrm{m}$ deep and 0.9$1.2 \mu \mathrm{m}$ in diameter. Surprisingly, the membrane of flagella inside the pocket was plicate and appeared to be involved in active exocytosis (Figs. 3c and 4c). The paraflagellar rod was perceptible starting from the middle 


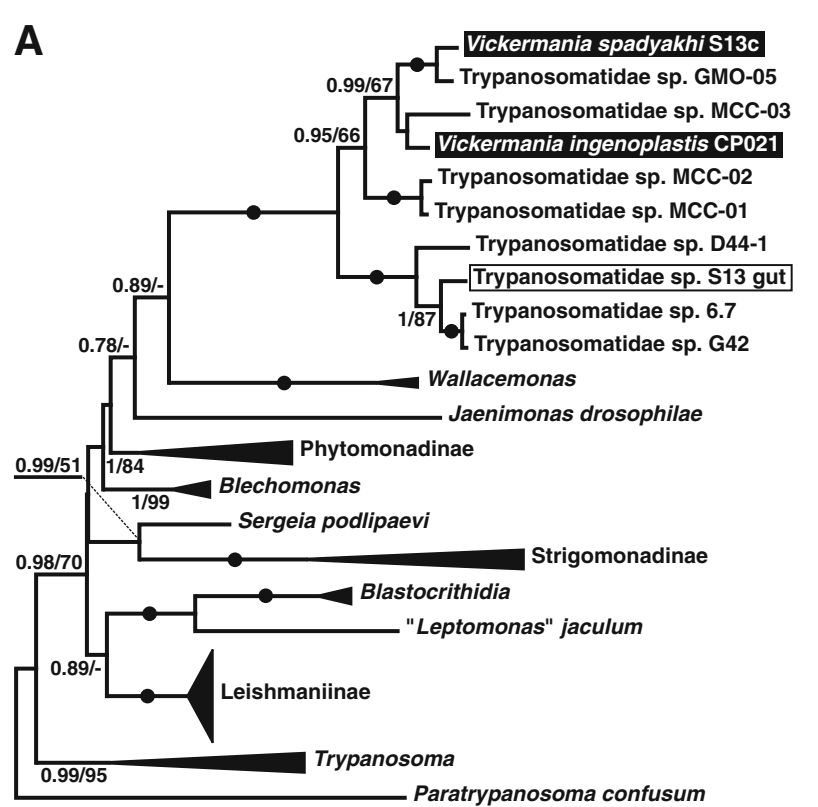

\section{$\longdiv { 0 . 0 2 }$}

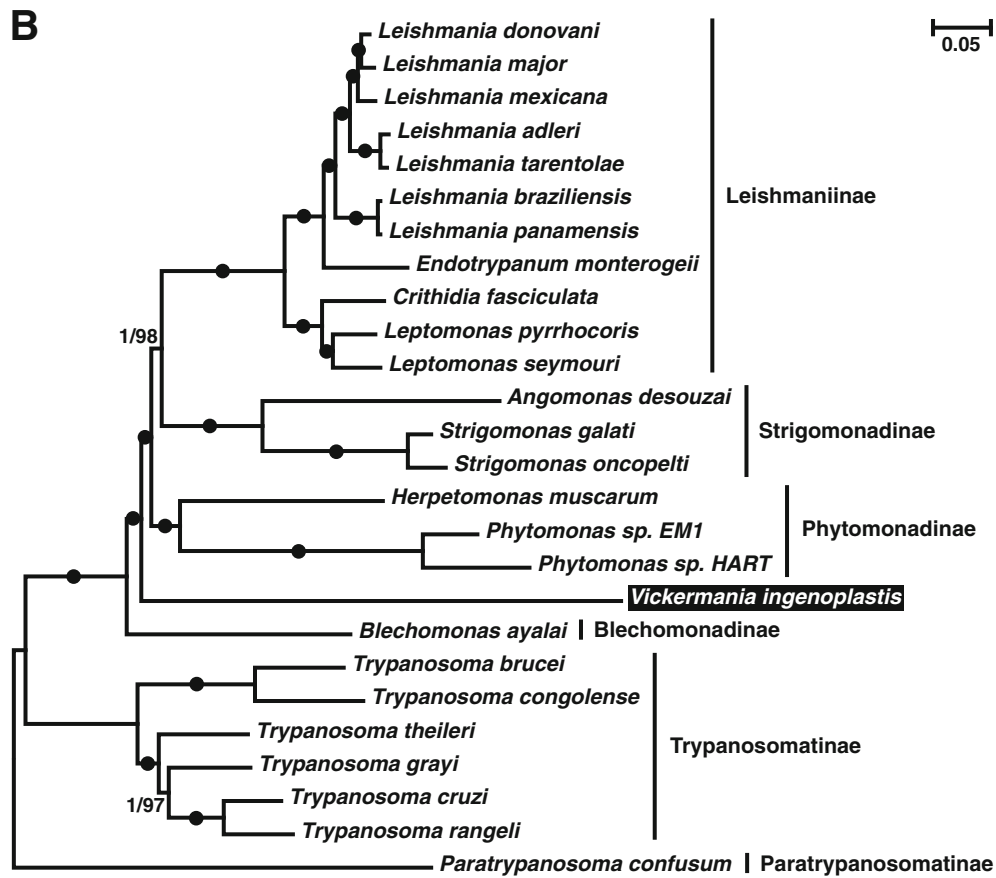

Fig. 2 Maximum likelihood phylogenetic trees of trypanosomatids. a Tree based on 185 rRNA gene sequences. $\mathbf{b}$ Tree based on 160 concatenated protein sequences. Numbers at nodes indicate posterior probability and bootstrap percentage, respectively. Values below 0.5 or $50 \%$ are replaced with dashes or omitted, absolute (1/100) supports are shown as black circles. The scale bar denotes number of substitutions per site. All clades representing described subfamilies or genera are collapsed in the $18 \mathrm{~S}$ rRNA gene-based tree. The two species of biflagellate trypanosomatids studied here are highlighted; the sample S13-gut from the naturally infected Nemopoda nitidula is boxed

part of the flagellar pocket (Figs. 3d and 4a, c, d), upon the exit of which the flagella became thicker owing to the increase of the flagellar matrix volume (Figs. 3a, c and $4 \mathrm{a}, \mathrm{c})$. In cross sections, the flagella outside the pocket were often seen close to each other or even adjacent, yet no specific structures could be observed at the site of the contact (Figs. 3e and 4e). In both examined species, the flagellar tip had a peculiar organization: a knob-like apex was situated distally to the ending of the axonemal microtubules, while proximally to it small lateral extensions were observed. These extensions were internally reinforced by oblique fibrils running from the peripheral microtubules of the axoneme to the flagellar membrane at an angle of $30-45^{\circ}$ (Figs. $3 \mathrm{~b}$ and $4 \mathrm{~b}$ ). 


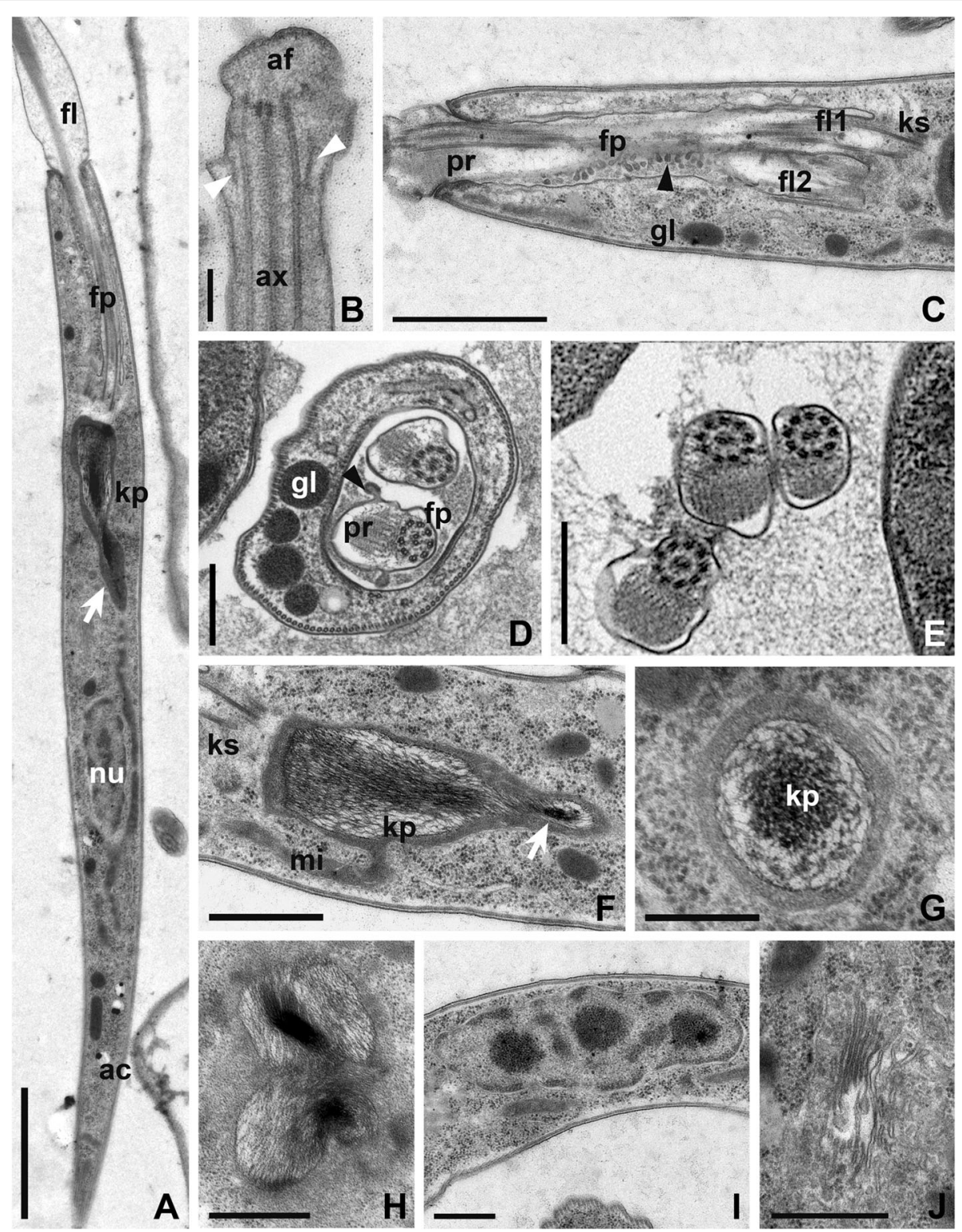

Fig. 3 Ultrastructure of the strain CP021. a General view of the anterior part of the cell. b Flagellar tip. c Longitudinal section through flagellar pocket. d Transverse section through a flagellar pocket with two flagella. e Four kinetosomes (indicated by numbers). $\mathbf{f}, \mathbf{g}$ longitudinal and transverse sections of the kinetoplast. $\mathbf{h}$ Dividing kinetoplast. i Golgi apparatus. $\mathbf{j}$ Interphase nucleus of irregular shape. Black arrowhead shows vesicles detaching from the flagellar membrane, white arrowheads — oblique fibrils between the axoneme and plasmalemma, white arrows — kinetoplast appendage containing kDNA fibrils, asterisk — microtubules supporting the flagellar pocket wall. Abbreviations: ac, acidocalcisomes; af, apex of the flagellar tip; ag, Golgi apparatus; ax, axoneme; fl, flagella; fp, flagellar pocket; gl, glycosomes; kp, kinetoplast; ks, kinetosomes; nu, nucleus; pr, paraxial rod. Scale bars: a 2 um, b $0.25 \mu \mathrm{m}, \mathbf{c}, \mathbf{e} 1 \mu \mathrm{m}, \mathbf{d}, \mathbf{f}-\mathbf{j} 0.5 \mu \mathrm{m}$

In both species, the cytoplasm contained multiple glycosomes, acidocalcisomes and a reticulated mitochondrion with rare cristae (Figs. $3 \mathrm{f}-\mathrm{h}$ and $4 \mathrm{a}, \mathrm{f}-\mathrm{h}$ ). The kDNA arrangement in these flagellates was unusual, with prominent differences between the two studied strains. In CP021, the kDNA mass had a dense longitudinally oriented central kernel and looser periphery (Fig. 3f, g). On average, it measured $2.1 \mu \mathrm{m}$ in length and $0.6 \mu \mathrm{m}$ in diameter (in its widest part). This mass possessed a posterior appendage that gave it the shape of a drop. In S13, the kDNA mass was barrel-shaped (Fig. 4f) with the height and the diameter at both ends being roughly equal $(0.6-0.8 \mu \mathrm{m})$ and the widest central part measuring $\sim 1 \mu \mathrm{m}$ in diameter. The kDNA in this trypanosomatid was distributed rather uniformly and in general looked looser as compared to CP021 (Fig. 4f, g). In both species, the kDNA divided along the longitudinal axis (Figs. 3h and 4h), and in CP021, the central 


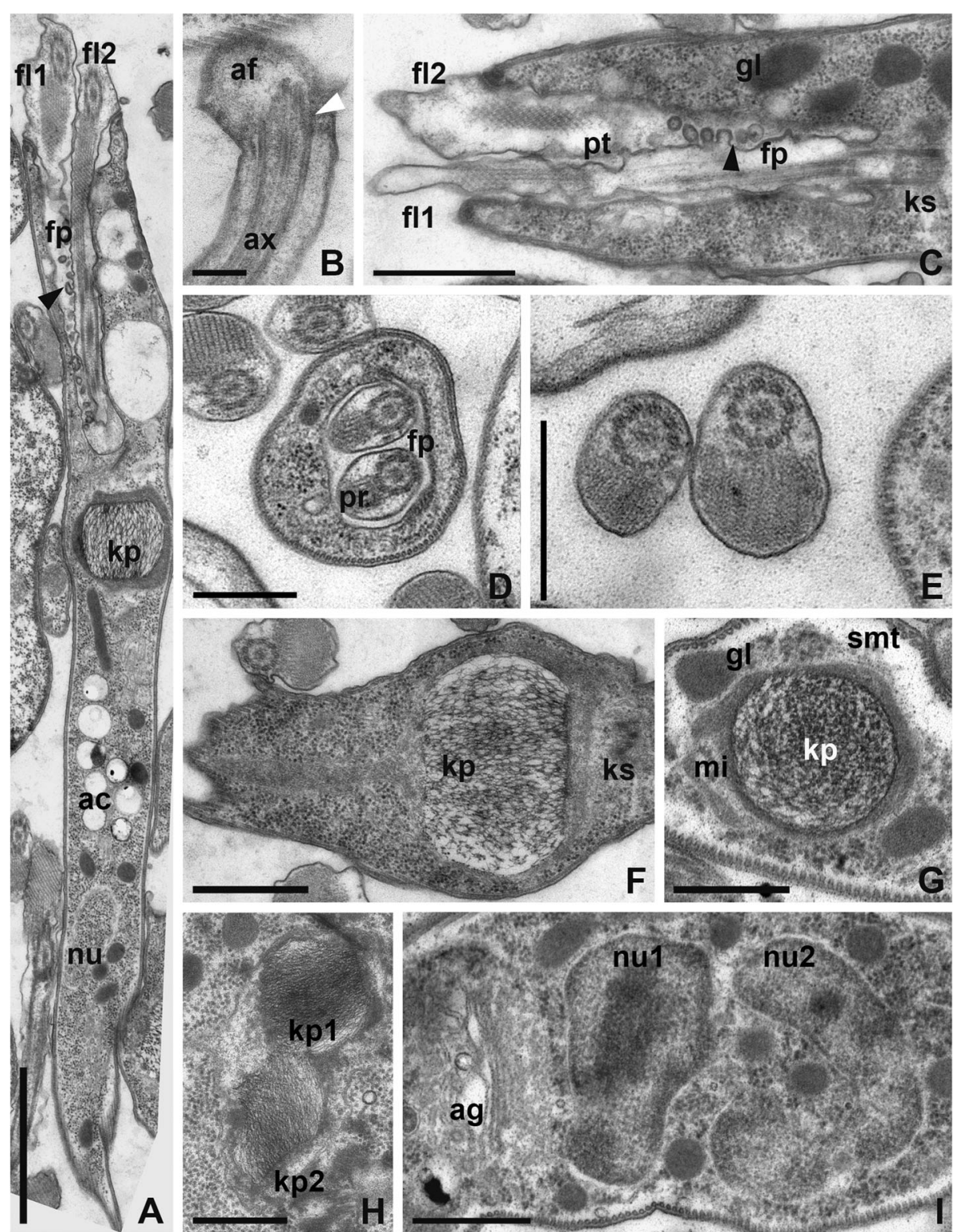

Fig. 4 Ultrastructure of the strain S13. a General view of the anterior part of the cell. b Flagellar tip. c Longitudinal section through flagellar pocket. d Transverse section through a flagellar pocket with two flagella. e Four kinetosomes (indicated by numbers). $\mathbf{f}, \mathbf{g}$ Longitudinal and transverse sections of the kinetoplast. $\mathbf{h}$ Dividing kinetoplast. i Golgi apparatus and two interphase nuclei of irregular shape. All symbols and abbreviations are the same as in Fig. 3. Scale bars: a $2 \mu \mathrm{m}, \mathbf{b} 0.25 \mu \mathrm{m}$, c, e $1 \mu \mathrm{m}, \mathbf{d}, \mathbf{f}-\mathbf{i} 0.5 \mu \mathrm{m}$

kernel became heavily condensed. Usually stretched along the longitudinal cell axis, the nuclei were mostly oval in CP021 and irregularly shaped in S13 (Figs. 3i and 4i). The Golgi apparatus composed of 8 to 10 cisternae was located between the kinetoplast and the nucleus (Figs. $3 \mathrm{j}$ and $4 \mathrm{i}$ ).

\section{Scanning electron microscopy}

Examination of the trypanosomatids under scanning electron microscope clarified any uncertainty regarding the number of flagella. In both species, the two flagella were tightly connected even in the cells starting cytokinesis (Fig. 5a). The shorter flagellum often remained connected by its tip to the longer one even if the flagella were partially separated (Fig. 5b). In the side view, the attached tips appeared tapered (Fig. 5c), while different shapes could be seen in the top view. In CP021, the flagellar tip was reminiscent of a crocodile head showing lateral extensions and an elongated central part, while in S13 it resembled a paddle with lateral extensions and a blunt apex (Fig. 5d, e). Free tips typically demonstrated more prominent (as compared to the attached ones) 

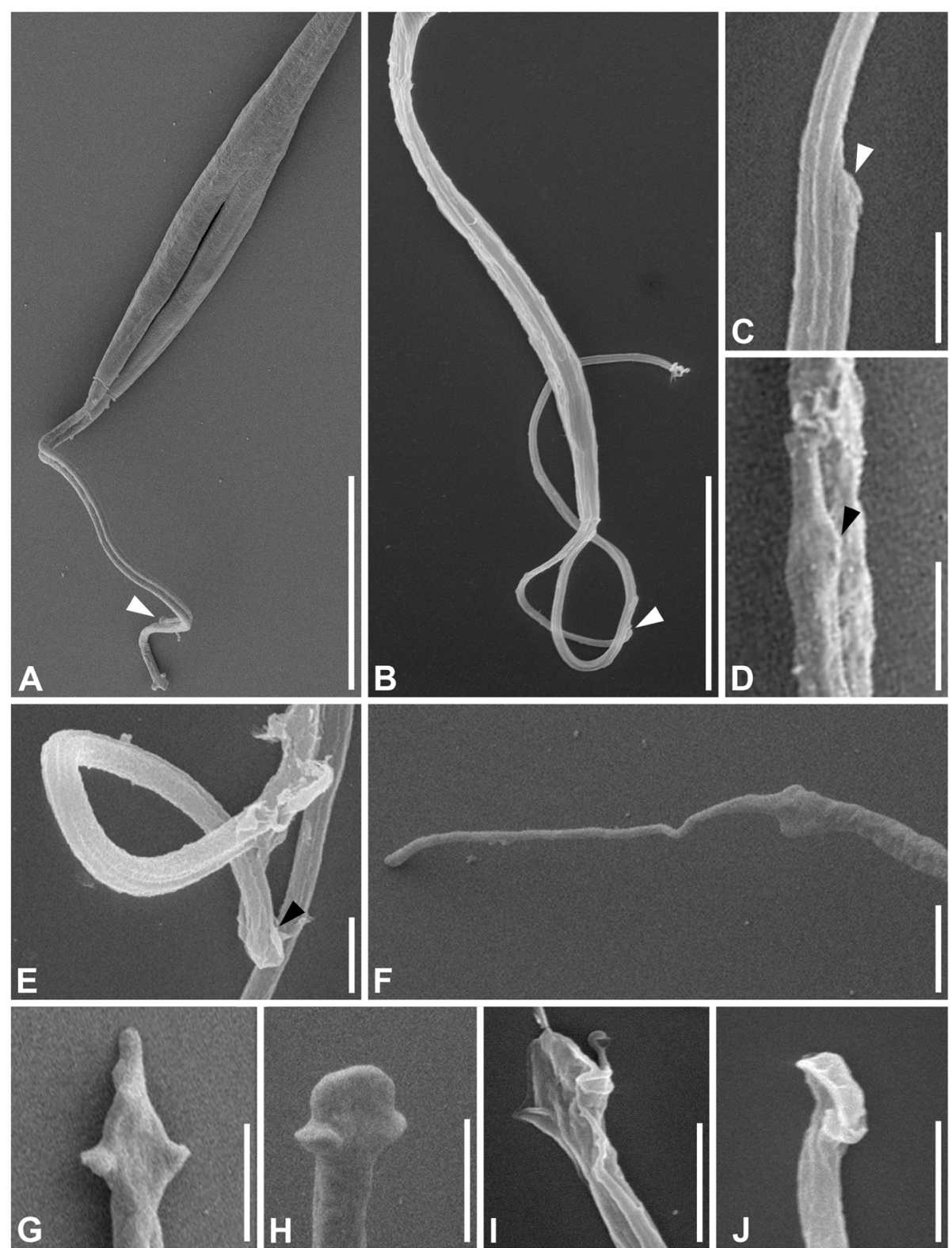

Fig. 5. Scanning electron microscopy of the strains CP021 and S13. a Joint flagella during cytotomy in CP021. b Non-dividing cell of S13: the second flagellum is attached only by its tip. $\mathbf{c}$ Lateral view of the tip of the second flagellum tightly connected to the first one in S13. $\mathbf{d}$ Top view of the second flagellum's tip in CP021; note the elongated distal part and lateral extensions. e Detaching flagellar tip in S13. $\mathbf{f}-\mathbf{j}$ Free flagellar tips in CP021 (f-h) and S13 (i, j). White arrowhead - tip of the second flagellum; black arrowhead-lateral extension of the flagellar tip. Scale bars: $\mathbf{a}$, b $10 \mu \mathrm{m}, \mathbf{c}-\mathbf{j} 1 \mu \mathrm{m}$

Table 1 Prevalence (infected/dissected ratio) of trypanosomatids in experimentally infected flies

\begin{tabular}{lllllll}
\hline Host/parasite combination & Day $\mathbf{1}$ & Day $\mathbf{3}$ & Day $\mathbf{5}$ & Day $\mathbf{1 5}$ & Isolation (day 20) & Horizontal transmission \\
\hline Calliphora vicina/CP021 & $3 / 3$ & $6 / 6$ & $0 / 10$ & $\mathrm{n} / \mathrm{a}$ & $\mathrm{n} / \mathrm{a}$ & $\mathrm{n} / \mathrm{a}$ \\
Calliphora vicina/S13 & $3 / 3$ & $6 / 6$ & $4 / 10$ & $4 / 9$ & $\mathrm{n} / \mathrm{a}$ & $0 / 10$ \\
Lucilia sericata/CP021 & $5 / 5$ & $5 / 8$ & $6 / 12$ & $3 / 7$ & $20 / 23$ & $0 / 20$ \\
Lucilia sericata/S13 & $5 / 5$ & $6 / 6$ & $6 / 6$ & $10 / 10$ & $20 / 20$ & $6 / 21$ \\
\hline
\end{tabular}


lateral extensions and had diverse apex shapes that were either filiform (Fig. 5f), triangular (Fig. 5g), or paddlelike (Fig. 5h) in CP021, and mostly paddle-like in S13 (Fig. 5i, j).

\section{Experimental infections}

Thirty minutes after the flies ingested the liquid containing trypanosomatids, the flagellates localized mainly in the crop, with one or two detected in the anterior midgut (data not shown). Starting from the first day postinfection, the promastigotes, the only observable morphotype, were present in all sections of the midgut except the proventriculus, with a few cells occasionally present in the hindgut and feces. Importantly, all flagellates were detected only in the endoperitrophic space and were never attached to any substrate (Additional file 5: Fig. S4).

The infection of Calliphora vicina by the CP021 strain was transitory, as no flagellates were observed 5 days post infection (Table 1). The S13 strain was able to inhabit this host for at least 15 days, but only about half of the flies remained infected, and the horizontal transmission experiments were not successful. Both trypanosomatids were able to survive in Lucilia sericata until the end of the experiments and single-infection longevity experiments showed high prevalence (87 and 100\% for CP021 and S13, respectively), yet only S13 could be horizontally transmitted (Table 1). The infections of $L$. sericata with small numbers of flagellates $(\sim 25)$ showed effective propagation of S13 (184-220 and 2260-2530 cells counted 3 and 5 days post-infection, respectively), while the numbers of CP021 gradually decreased (3-12 and $0-2$ cells for days 3 and 5 , respectively). Hence, $L$. sericata was selected as a model host for a subsequent study of the cell cycle in vivo.

\section{Cell cycle}

In order to investigate the dynamics of the flagella during the cell cycle, the axonemes and DNA in nuclei and kinetoplasts were visualized using antibodies against alpha-tubulin and DAPI or SYTO24 dyes, respectively. The studies were performed using cells of both species in cultures and from the intestine of experimentally infected $L$. sericata flies (Table 2). In all cases, the most abundant ( $>57 \%$ ) cell type with two flagella, one nucleus and one kinetoplast (Fig. 6a), cells undergoing regular division (Fig. 6b-d), and those with a single nucleus, kinetoplast and flagellum (Fig. 6e), constituted overwhelming majority $(\sim 89 \%$ in cultures and $\sim 98-99 \%$ in the gut) (Table 2). Importantly, in both species, cells with more than two flagella were observed only in the culture and appeared to be associated with division anomalies (Fig. 6f-i). Hence, the normal cell cycle includes alternation of the biflagellate and uniflagellate stages, with the latter being the product of a recent division of the former. Of note, CP021 demonstrated dramatic depletion of dividing cells in the gut as compared to the culture, while in S13 the proportions of such cells did not differ between these conditions (Table 2).

The second flagellum appears to grow continuously. Even in the dividing cells, it is always shorter and its average ratio in length to the first one is roughly equal in both species, $0.81 \pm 0.09(0.56-0.98)$ in CP021 and $0.80 \pm 0.10(0.61-0.99)$ in S13. This suggests that the flagella continue growing even after the completion of cell division.

\section{Analysis of cell motility}

In order to test the hypothesis that the flagella separation results in lowered motility, we performed a comparative analysis of in vitro swimming behavior for two cell categories: (1) with two separate flagella and (2) with a single or two joint flagella. The cells with separate flagella showed significantly lower values of average speed, maximum displacement and absolute speed changes (estimated as standard deviation [SD] of speed) being a proxy for agility (Fig. 7; Additional file 6: Table S2). The differences were so pronounced that interquartile ranges

Table 2 Proportions of different types of cells in cultures and experimentally infected flies

\begin{tabular}{|c|c|c|c|c|c|c|}
\hline & \multicolumn{5}{|c|}{ Number of flagella/nuclei/kinetoplasts } & \multirow{2}{*}{$\begin{array}{l}\text { Sample } \\
\text { size }\end{array}$} \\
\hline & $2 / 1 / 1$ & $1 / 1 / 1$ & $2 / 2 / 2,2 / 1 / 2,2 / 2 / 1$ & $>2$ flagella & Others & \\
\hline \multicolumn{7}{|l|}{$\overline{\mathrm{CP} 021}$} \\
\hline culture & $60.9 \%$ & $16.3 \%$ & $12.0 \%$ & $5.8 \%$ & $5.1 \%$ & 276 \\
\hline gut & $80.8 \%$ & $16.4 \%$ & $0.7 \%$ & $0.0 \%$ & $2.1 \%$ & 287 \\
\hline$p$ value* & $<0.001$ & 0.97 & $<0.001$ & $<0.001$ & 0.055 & \\
\hline \multicolumn{7}{|l|}{ S13 } \\
\hline culture & $57.5 \%$ & $23.6 \%$ & $7.5 \%$ & $4.7 \%$ & $6.6 \%$ & 212 \\
\hline gut & $64.3 \%$ & $28.4 \%$ & $6.2 \%$ & $0.3 \%$ & $0.5 \%$ & 370 \\
\hline$p$ value* & 0.1 & 0.21 & 0.55 & $<0.001$ & $<0.001$ & \\
\hline
\end{tabular}

*Calculated using $x^{2}$ test 

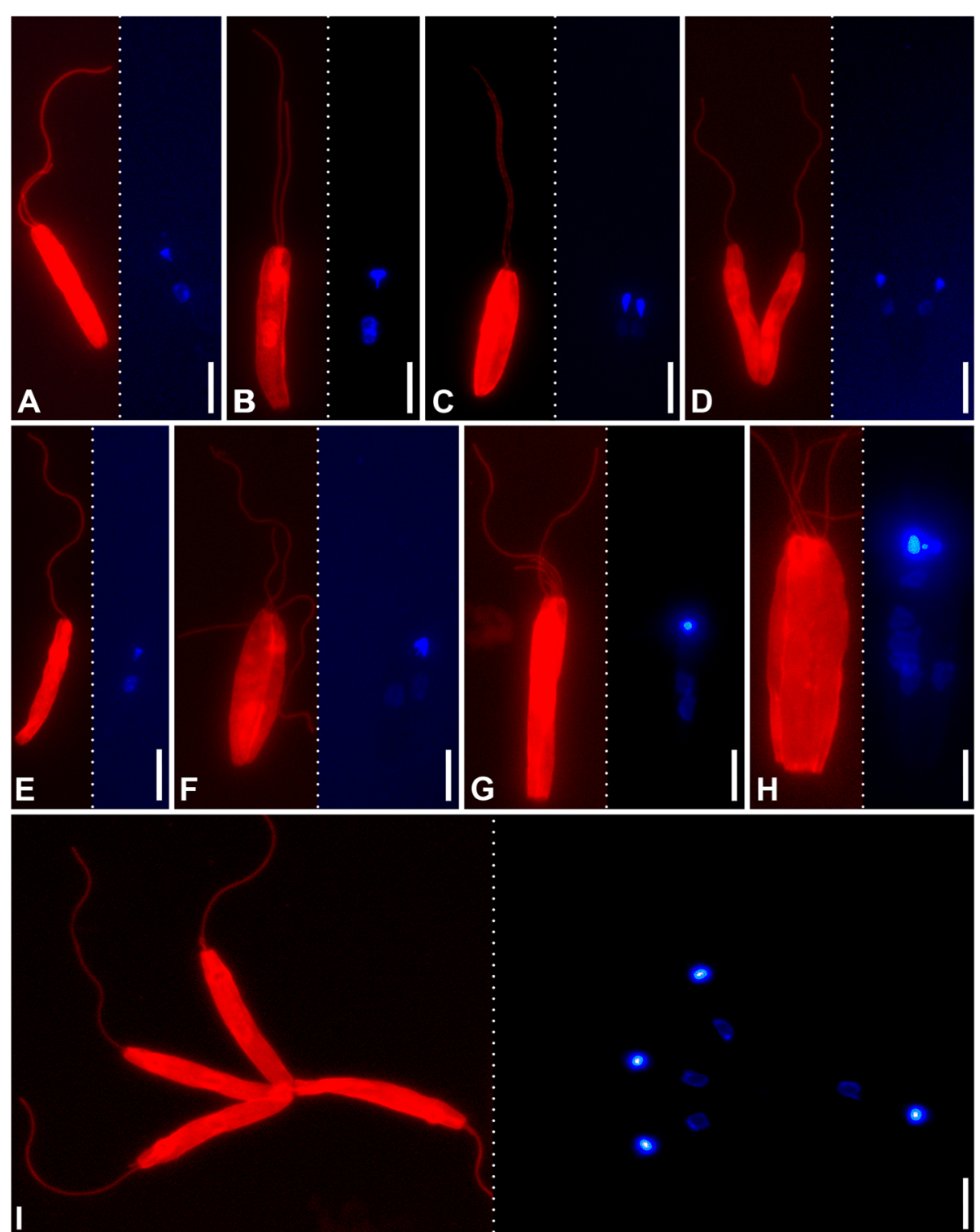

Fig. 6. Various stages of the cell cycle and division anomalies. Fluorescent visualization using anti-a-tubulin antibodies and DAPI are shown on the left and right subpanels, respectively. a-f CP021 strain. $\mathbf{g}-\mathbf{i}$ S13 strain

for all these parameters in the two cell categories did not overlap (Fig. 7). Expectedly, average speed and maximum displacement showed statistically significant correlation in both cell categories, while the intuitive correlation of the average speed and absolute speed changes (faster cells lose more speed when changing direction and accelerate more on nearly straight trajectory sections) could be observed only for the category 2 (Additional file 7: Table S3). At the same time, only the category 1 displayed a moderate correlation between the absolute and relative speed changes (relative SD of speed). This agreed with significantly greater (as judged by Wald-Wolfowitz runs test) variation of relative speed changes in the category 1 , as compared to its counterpart, while the differences in median values were negligible (Fig. 7; Additional file 6: Table S2). This can be interpreted as more uniform speed patterns in the category 2 , representing predominant ( $\sim$ normal) cells, while disturbances of motility caused by flagella separation lead to increase in the spectrum of aberrations. Moreover, inspection of the cell trajectories suggests that faster cells of the category 1 make less turns than those in the category 2, i.e., they are less agile (Additional files 8, 9: Suppl. Fig. S5, S6). 


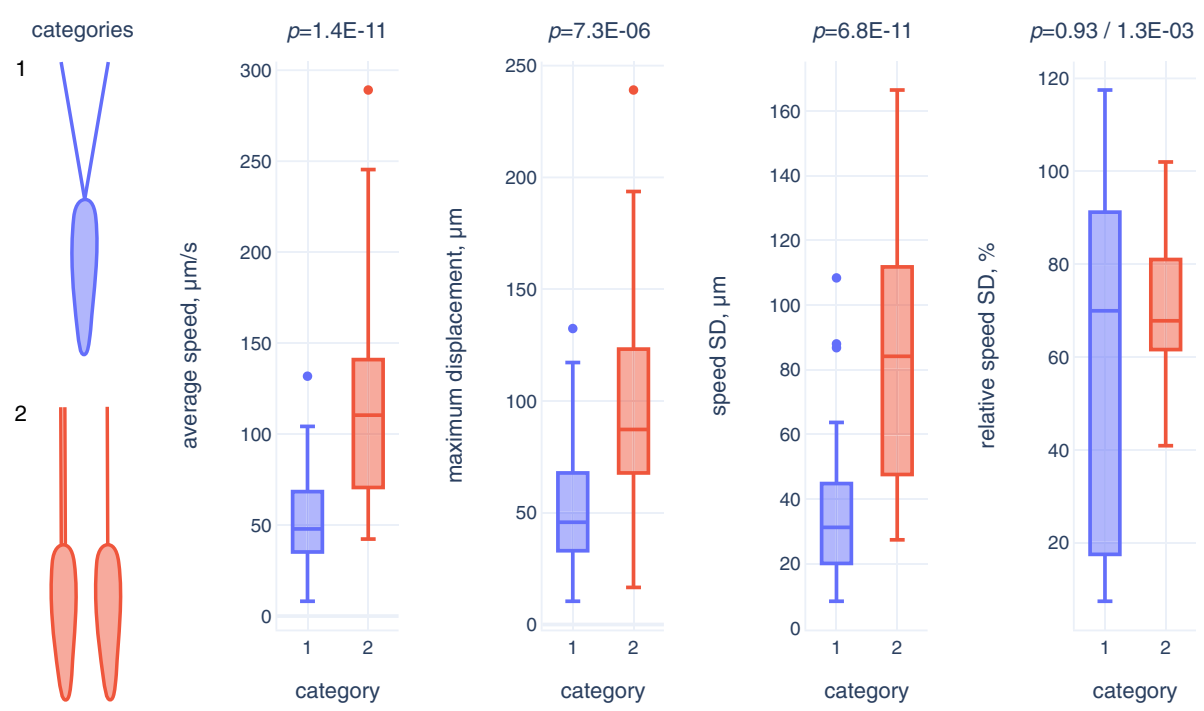

Fig. 7 Comparative analysis of cell motility. Two categories of cells (with two separate flagella and with a single or two joint flagella) are compared. The boxes and whiskers correspond to interquartile and non-outlier ranges, respectively. Mann-Whitney $U$ test only or both Mann-Whitney $U$ test and Wald-Wolfowitz runs test $p$ values are shown above the graphs

\section{Taxonomic summary}

Since this publication contains nomenclatural changes, it has been registered in Zoobank: urn:lsid:zoobank.org: pub:73A2FCA2-F35B-4050-8EE7-DCAFCAEBD770.

Class: Kinetoplastea Honigberg, 1963

Order: Trypanosomatida Kent, 1880

Family: Trypanosomatidae Doflein, 1901

Genus: Vickermania Kostygov et Yurchenko, 2020 gen. nov.

Zoobank LSID: urn:lsid:zoobank.org:act:F31B2BA7A896-49B8-A5CF-4A6F3BD4FB6F

Diagnosis: promastigotes with two anteriorly oriented flagella of unequal length, typically attached to each other, separated only during cell division; uniflagellate cells appear only shortly after division, as the second flagellum starts growing soon after it; flagellar tips have rounded or elongated apex and lateral extensions; large and loosely arranged kDNA.

Name-bearing type: Herpetomonas muscarum ingenoplastis Rogers and Wallace, 1971 now classified as Vickermania ingenoplastis

Etymology: The generic name honors Prof. Keith Vickerman, an outstanding British protistologist, who focused on studies of various parasitic protists, mainly trypanosomatids.

Vickermania ingenoplastis (Rogers et Wallace, 1971) comb. nov., stat. nov.

Species diagnosis and description: up to $80 \%$ cells in culture are biflagellate; cells are $27.3-40.7 \mu \mathrm{m}$ long and $2.3-3.5 \mu \mathrm{m}$ wide; flagellum is $28.8-44.5 \mu \mathrm{m}$ long; $\mathrm{kDNA}$ mass is about $2.1 \mu \mathrm{m}$ long, $0.6 \mu \mathrm{m}$ in diameter and has grape seed shape; it has loose periphery, and dense kernel.

Type host: Phormia regina (Diptera: Calliphoridae)

Localization: midgut

Type locality: Minneapolis-Saint Paul, Minnesota, USA.

Type material: the culture ATCC30259.

Gene sequences: MT241904 (18S rRNA gene), and MT248932 (gGAPDH gene), KX901631 (draft genome).

Comments: (i) opisthomastigotes and short promastigotes reported in the original description [26] were not observed in our study neither in the culture nor during the development in the host gut and most likely had represented an admixture by some Herpetomonas sp., which was lost as a result of long-term cultivation; (ii) the culture F72 isolated from Lucilia sericata (Calliphoridae) in Oksochi, Novgorod Oblast, Russia $\left(58^{\circ} 39^{\prime} \mathrm{N}, 32^{\circ} 7^{\prime} \mathrm{E}\right)$, belongs to the same species according to the $18 \mathrm{~S}$ rRNA gene sequences.

Vickermania spadyakhi Ganyukova et Kostygov sp. nov.

Zoobank ID: urn:lsid:zoobank.org:act:D68B3910-9D91402B-8FEC-2CF9AF1506AF.

Species diagnosis and description: up to $60 \%$ cells in culture are biflagellate; cells are $22.5-75.9 \mu \mathrm{m}$ long and $1.8-4.7 \mu \mathrm{m}$ wide; flagellum is $25.6-64.0 \mu \mathrm{m}$ long; barrelshaped $\mathrm{kDNA}$ mass with diameter of $0.6-0.8 \mu \mathrm{m}$ at both ends and $1 \mu \mathrm{m}$ in center.

Type host: Nemopoda nitidula (Diptera: Sepsidae)

Localization: midgut

Type locality: Sob' railway station, Yamalo-Nenets Autonomous Okrug, Russia $\left(67^{\circ} 06^{\prime} \mathrm{N}, 65^{\circ} 71^{\prime} \mathrm{E}\right)$ 
Type material: the culture S13, deposited in the research collection of Parasitic Protists of the Zoological institute RAS (St. Petersburg, Russia).

Etymology: the specific epithet has Russian origin and means "from near Padyakha", referring to the local name of the river Sob', close to which the species was collected.

Gene sequences: MT241903 (18S rRNA gene), and MT248930 (gGAPDH gene).

Comment: the type culture was established from an insect with a mixed infection, including morphologically dissimilar epimastigote-type cells with a distinct phylogenetic position.

\section{Discussion}

Since the description of biflagellate trypanosomatids more than a century ago by Stanislav Provázek, the discoverer of epidemic typhus [18], their very existence was repeatedly questioned, as it conflicted with the idea that a single flagellum is a distinctive feature of the family Trypanosomatidae, clearly separating them from other kinetoplastids, which are biflagellate or aflagellate [45]. However, the records of this peculiar morphotype from a range of fly hosts in different geographic areas [18, 26, $27,46]$, and the fact that both flagella are usually glued together, prove that this is not an abnormality but a stable morphological adaptation.

Our study confirmed that Vickermania is not truly biflagellate in the sense that it lacks a tetraflagellate stage prior to the cell division, but instead becomes transiently uniflagellate right after its completion. However, these trypanosomatids bear two flagella throughout most of their cell cycle and, in this respect, shall be considered biflagellate. In order to achieve this, Vickermania had to disconnect the well-established ancestral coordination of the cell cycle, and this results in a relatively high percentage of anomalous forms associated with various cell division disturbances.

Why did then Vickermania become biflagellate? Taking into account that the main function of the flagellum is locomotion [47], this is likely to be related to cell motility. Indeed, it seems to be important for cell survival as judged by long flagella strengthened by a thick paraflagellar rod. Although it is tempting to speculate that two flagella ensure more efficient movement, this seems unlikely. Firstly, the uniflagellate cells constitute a significant proportion and are not depleted in the gut, where the conditions are more restrictive than in the culture. Secondly, in many biflagellate cells, the second flagellum is rather short and can hardly enhance motility. While in a typical trypanosomatid the second flagellum appears only at the end of the cell cycle and is not connected to the old one [33], Vickermania preserves a connection between the two flagella for as long as possible. This allows them acting as a single entity, not interfering with each other due to possible uncoordinated beating. Our analysis of motility confirmed that the cells with a single or two joint flagella are significantly faster and more agile as compared to those with two separate flagella. The observed low frequency of cells with separate flagella in the log-phase and its increase only in degrading post-stationary cultures further supports this assumption. In order to build the new flagellum in time, the trypanosomatid starts growing it in the very beginning of the cell cycle. The peculiar "seizing" structure of the flagellar tips likely mediates a firm attachment and a proper orientation of the growing flagellum.

Why may motility be of higher importance to Vickermania than to other trypanosomatids? As highly diverse and successful parasites, trypanosomatids evolved a range of strategies allowing them to colonize a wide range of hosts [48]. The evolutionarily primary and still most frequent localization of these flagellates within the insect host is the intestine [49], which allows direct access to the digested food, while both the entry and exit from this organ are straightforward. However, the parasites have to evolve adaptations preventing their premature discharge, typically by attaching to the intestinal wall via various modifications of the flagellum [50-58]. Although Vickermania thrives in the midgut, it cannot implement attachment, since in its fly host the midgut wall is separated from the lumen by a semipermeable continuous structure known as the peritrophic membrane [59]. It is produced by secretory cells at the midgut entrance, continuously grows in the posterior direction, becomes partially destroyed in the hindgut, and is eventually discharged with feces [60]. Attachment to this structure would lead to a rapid removal of flagellates from the gut. Some intestinal protists such as human-infecting Leishmania spp. can penetrate this barrier during their development in sandflies [61]. However, the peritrophic membrane of sandflies is short-lived and starts disintegrating at about the third day post blood meal (long before defecation), significantly facilitating the escape of parasites [62]. A coexistence with the permanent peritrophic membrane apparently forced Vickermania to rely only on an active movement against the flow created by intestinal peristalsis. In such harsh conditions, dividing cells are vulnerable due to their decreased motility. Indeed, in the strain CP021, which showed lower infection efficiency in the model fly species (probably because it had been already cultivated for over 50 years), the proportion of dividing cells displayed a dramatic drop during development in the gut. Since bearing two separate flagella in such conditions can make cells vulnerable, Vickermania has shortened this period. Regrettably, very little is known about the 
development of other monoxenous trypanosomatids inhabiting the fly midgut [49], and therefore, it is not possible to compare the efficiency of this and alternative strategies.

The procyclic trypomastigotes of Trypanosoma brucei live in the endoperitrophic space of the tsetse fly midgut, where they also have no chance to attach to the intestinal wall. Interestingly, this developmental stage demonstrates a surprising analogy to Vickermania, as its newly growing flagellum is also connected by the tip to the old one [63]. However, the mechanism utilized by $T$. brucei is different: it developed for this purpose a specialized structure called the flagella connector, which is absent from all other developmental stages [64]. This structure was proposed to mediate inheritance of a cellular pattern [65], but in the light of our study can be seen from a different perspective. The alternative reason may be retaining efficient motility by preserving coordination between the two flagella, a critical requirement for survival in the fly midgut. Indeed, the principle of the Red Queen "it takes all the running you can do, to keep in the same place", seems to be particularly fitting here. However, T. brucei eventually migrates from the intestine into the salivary glands, where it becomes attached to the epithelium, while Vickermania is doomed to permanent movement.

\section{Conclusions}

The new genus Vickermania represents overlooked, yet widely distributed trypanosomatids that adapted to the life in the fly midgut, where the default trypanosomatid strategy, namely the attachment to the intestinal epithelium, is impossible. Instead, they rely on constant movement, preventing discharge from the host gut due to intestinal peristalsis. Therefore, these parasites shortened the period of the cell cycle, when they bear two separate flagella interfering with each other and thus become vulnerable. This is achieved by disconnecting the flagella duplication from cell division and by developing a mechanism to join the new growing flagellum with the old one. Our findings also shed light on the biology of the deadly human pathogen Trypanosoma brucei. During development in the tsetse fly midgut, it likely faces the same conditions and follows the same strategy as Vickermania. The flagella connector, unique for the gut stage of T. brucei, and the peculiar seizing structure at the tip of the Vickermania flagellum developed independently, but play the same role ensuring efficient motility in dividing cells. These remarkably analogous adaptations demonstrate the plasticity of one of the main eukaryotic cellular structures, the flagellum.

\section{Methods}

\section{Trypanosomatid strains: origin and cultivation}

The CP021 culture of $H$. m. ingenoplastis was obtained from the Fiocruz Protist Culture Collection. It is a replicate of the type culture ATCC30259, isolated from Phormia regina (Calliphoridae) [26]. The culture S13 originated from the midgut of the fly Nemopoda nitidula (Sepsidae) collected in July 2016 near Sob' railway station $\left(67^{\circ} 06^{\prime} \mathrm{N}, 65^{\circ} 71^{\prime} \mathrm{E}\right)$, Yamalo-Nenets Autonomous Okrug, Russia, as described elsewhere [66]. The intestinal fragments of the infected fly were also smeared for microscopy and used for DNA isolation (sample S13gut). The culture F72 was isolated from the midgut of Lucilia sericata (Calliphoridae) captured in May 2019 in the village Oksochi $\left(58^{\circ} 39^{\prime} \mathrm{N}, 32^{\circ} 47^{\prime} \mathrm{E}\right)$, Novgorod Oblast, Russia. To date it could not be purified from the accompanying fungal contaminants.

All trypanosomatid cultures were maintained at $23^{\circ} \mathrm{C}$ in Schneider's Drosophila medium (Sigma-Aldrich, St. Louis, USA) supplemented with $10 \%$ fetal bovine serum (FBS) (Thermo Fisher Scientific, Waltham, USA), $500 \mu \mathrm{g} / \mathrm{ml}$ of streptomycin and 500 Units $/ \mathrm{ml}$ of penicillin (Sigma-Aldrich), and passaged weekly. In order to study growth dynamics, the cultures CP021 and S13 were seeded in hexaplicates with a starting concentration of 40,000 cells $/ \mathrm{ml}$ and subsequent counting with hemocytometer at days 1, 2, 3, 5, 7, 9, and 11 .

\section{Experimental infections}

Experimental infections were performed using laboratory cultures of the flies Calliphora vicina and Lucilia sericata (both Calliphoridae), maintained at the Zoological Institute, St. Petersburg, since 2010. The insects were cultivated at $25^{\circ} \mathrm{C}$, with larvae being fed pork liver, while adults received sugar cubes and clean water. Two days after hatching from pupae, $50 \%$ of individuals were used for experiments, while the remaining half underwent control dissection and were always trypanosomatidnegative. Before the experiments, the flies were kept without water for $24 \mathrm{~h}$.

The thirsty flies were given access to a bowl containing flagellates in cultural medium, which was replaced after $24 \mathrm{~h}$ with clean water. From that moment, the time of infection was counted and the dissections were performed on days $1,3,5$, and 15 . The possibility of intraspecific horizontal transmission was tested by placing 5 uninfected flies with 5 recently (1-2 days) infected ones. Ten days later, all insects were dissected.

In order to assess the duration of single infections, individual infected flies were isolated in plastic tubes of a diameter that prevented them from turning around and, thus, being re-infected with their own feces. The tube opening was closed with a fine-meshed net, through which the fly had access to a piece of cotton wool soaked in $17 \%$ sugar syrup. At the posterior end, the tube contained a piece of dry cotton wool absorbing excreta (Additional file 10: Fig. S7). 
For determining the efficiency, localization, and propagation of an infection initiated with a small parasite dose, flies were given a $5-\mu \mathrm{l}$ drop of the culture medium containing $\sim 25$ trypanosomatid cells, and 5 individuals were dissected at $30 \mathrm{~min}, 3$ and 5 days post-infection.

The work with flies did not require specific permissions, since they do not belong to an endangered or protected species.

\section{Microscopy}

The trypanosomatid cells on Giemsa-stained smears were photographed using DM 2500 Leica microscope and measured with Fiji software [67]. For fluorescent microscopy, cells from either 3-day-old culture or the intestinal contents of flies infected 3 days before were centrifuged, fixed with $4 \%$ paraformaldehyde in phosphate-buffered saline (PBS) for $30 \mathrm{~min}$, rinsed with PBS, attached to poly-L-lysine-coated slides, permeabilized with $1 \%$ Triton X-100, and blocked with 1\% Bovine Serum Albumin (Sigma-Aldrich). For the visualization of axonemes, primary mouse monoclonal anti- $\alpha$-tubulin and secondary anti-mouse IgG-TRITC goat antibodies (1:500 and 1:100, respectively; both from Sigma-Aldrich) were used. After washing with PBS and staining with either DAPI $\left(4^{\prime}, 6^{\prime}\right.$-diamidino-2phenylindole; Sigma-Aldrich) or SYTO24 Green Fluorescent Nucleic Acid stain (Thermo Fisher Scientific), slides were observed under Leica DM2500 fluorescent microscope. The samples from cultures and midguts of infected flies were prepared and processed for scanning and transmission electron microscopy as described previously $[8$, $68,69]$.

\section{DNA isolation, amplification, cloning, and sequencing}

Total genomic DNA from cultures and one field sample was isolated with the DNeasy Blood \& Tissue Kit (Qiagen, Hilden, Germany). 18S rRNA and gGAPDH genes were amplified using the primer pairs S762/S763 [70] and M200/M201 [71], respectively, and sequenced.

\section{Phylogenetic analyses}

The phylogenetic position of the studied trypanosomatids was inferred based on the analyses of $18 \mathrm{~S}$ rRNA and gGAPDH genes commonly used for this groups as well as more powerful phylogenomic analysis.

Seventy-four 18S rRNA gene sequences of various trypanosomatids including the two species under study (Additional file 11: Table S4) were aligned in MAFFT v. 7.450 using the E-INS-i method [72]. Poorly aligned positions were removed with Gblocks v. 0.91b [73], as described previously [74]. Maximum likelihood (ML) analysis was made in IQTREE v. 1.6.12 [75] under the model SYM + I + G4 rated as the best one by the builtin ModelFinder [76]. Edge support was assessed using 1000 "standard" bootstrap replicates. Bayesian inference was performed in MrBayes v. 3.2 .7 [77] under the GTR + I + G model (4 gamma categories) with 2 million generations, sampling frequency set to 200 and other parameters left in default states.

Fifty amino acid sequences of gGAPDH (Additional file 12: Table S5) were aligned in MAFFT using the L-INS-i method and the resulting alignment was trimmed with Gblocks as above. The phylogenetic inference was performed essentially as above, with a few differences specified below. The best amino acid substitution model selected by ModelFinder was LG + I + G4. In MrBayes, the amino acid model prior was set to "mixed" resulting in 1.0 posterior probability of WAG substitution matrix, and it took 3 million generations for the runs to achieve convergence.

The genomic sequences of 26 trypanosomatid species representing all lineages, for which such data are available, were retrieved from the GenBank and TriTryp databases (Additional file 13: Table S6). Inference if orthologous gene groups using OrthoFinder v. 2.2.7 with default settings [78] revealed 624 proteins encoded by single-copy genes. Sequence alignment and trimming were performed using MUSCLE v. 3.8.31 [79] and Tri$\mathrm{mAl}$ v. $1.2 \mathrm{rev} 59$ with the "-strict" option, respectively [80]. The final 45,802 aa-long dataset of 160 proteincoding genes was obtained after applying the following thresholds: minimum $60 \%$ average sequence identity as well as maximum $40 \%$ and $10 \%$ of gaps before and after the trimming, respectively. ML analysis was performed in IQTREE using the LG + C60 + F + G4 with PMSF approximation [81] and edge support estimated by 1000 standard bootstrap replicates. Bayesian inference was carried out in PhyloBayes-MPI v. 1.8 with the LG + CAT + F + G4 model with two parallel chains run for 17,000 iterations [82]. The maximum clade credibility tree was obtained by summarizing all sampled trees but the first 200 removed as burn-in.

\section{Analysis of cell motility}

Cells of the 3-4-day-old S13 culture were transferred to non-coated microscopic slides, covered with $24 \times 24 \mathrm{~mm}$ coverslips, and examined with $40 \times$ objective. This magnification ensured observation of moving parasites for a reasonable time and an opportunity to discriminate the following two categories of cells: (i) with two separate flagella and (ii) with a single or two joint flagella. Videos were recorded at a $720 \times 480$ pixels resolution with frame rate of $30 \mathrm{fps}$ and then cut into 100 (50 per cell category) 3-s clips for each cell to be analyzed. The cells were selected according to the following criteria: (i) moving actively; (ii) showing no signs of cytotomy, abnormal size, or cell body deformation; and (iii) appearing in the examination area for at least $3 \mathrm{~s}$. The frame-wise coordinates of each cell central point were obtained with 
the Manual Tracking plugin in Fiji software and used to calculate the following parameters: (i) average speed; (ii) maximum displacement, i.e., maximum distance between any two points on the trajectory; (iii) speed standard deviation (SD); and (iv) relative speed SD, i.e., SD of speed changes expressed as a percentage of an average value. Since all obtained per-category distributions significantly differed from normal as judged by $\chi^{2}$ test (Additional file 6: Table S2), Mann-Whitney $U$ test and Wald-Wolfowitz runs test were used for their comparisons.

\section{Supplementary information}

The online version contains supplementary material available at https://doi. org/10.1186/s12915-020-00916-y

Additional file 1: Figure S1. Cells on a Giemsa-stained smear from the xenic culture F72. a Cell appearing as monoflagellate. b Unambiguously biflagellate cell.

Additional file 2: Table S1. Measurements (in $\mu \mathrm{m}$ ) of trypanosomatid cells in three cultures $(N=50)$. A-N and $A-K$ are the distances between the anterior end of the cell and nucleus or kinetoplast, respectively.

Additional file 3: Figure S2. Growth dynamics of the cultures CP021 and S13 with values averaged from six independent biological replicates. Confidence bars indicate standard deviations.

Additional file 4: Figure S3. Maximum likelihood phylogenetic tree based on gGAPDH gene sequences. Numbers at nodes indicate posterior probability and bootstrap percentage, respectively. Values below 0.5 or $50 \%$ are replaced with dashes or omitted. The tree is rooted with the sequence of Paratrypanosoma confusum. All well-supported clades of described subfamilies or genera are collapsed. The scale bar denotes number of substitutions per site. The two species of biflagellate trypanosomatids studied here are highlighted.

Additional file 5: Figure S4. Flagellates of the strain S13 in the gut (SEM). Abbreviations: tr, trypanosomatids; pm, peritrophic membrane. Scale bar: $20 \mu \mathrm{m}$

Additional file 6: Table S2. Summary statistics for motility parameters in two cell categories and results of statistical tests.

Additional file 7: Table S3. Correlation of motility parameters in two cell categories.

Additional file 8: Figure S5: Three-second trajectories of the cells of the category 1

Additional file 9: Figure S6: Three-second trajectories of the cells of the category 2

Additional file 10: Figure S7. Individually isolated flies in infection longevity experiments.

Additional file 11: Table S4. Sequences of 185 rRNA gene used in this work.

Additional file 12: Table S5. Sequences of gGAPDH gene used in this work.

Additional file 13: Table S6. Genomic sequences used in this work.

\section{Abbreviations}

DAPI: 4'6'-Diamidino-2-phenylindole; FBS: Fetal bovine serum; gGAPDH: Glycosomal glyceraldehyde-3-phosphate dehydrogenase : kDNA: Kinetoplast DNA; ML: Maximum likelihood; PBS: Phosphate-buffered saline: SD: Standard deviation

\section{Acknowledgements}

We thank members of our laboratories for stimulating discussions.

\section{Authors' contributions}

AYK, VY, AOF, and JL designed the study. AOF and AIG isolated new trypanosomatid cultures. CdAL, DM, and MNM maintained cultures and optimized cultivation conditions. DM, JR, AOF, and AIG performed light microscopy analyses. AIG and DT studied culture growth dynamics. AOF, MNM, AIG, and MT performed electron microscopical studies. AK and JR investigated cell motility. AYK, WS, and AB completed molecular phylogenetic analyses. AIG carried out experimental infections. LVC and DT performed fluorescent microscopy studies. AYK and AOF drafted the manuscript. AYK, JL, DT, CAL, and VY edited the final draft. All authors read and approved the final manuscript.

\section{Funding}

This work was supported by the Russian Science Foundation grant 18-1400134 to AOF, MNM, AIG, and AYK (material collection, light and electron microscopy for S13 and experimental infections); State Assignment for the Zoological Institute AAAA-A19-119020690109-2 to LVC, the ERD Funds of the Czech Ministry of Education (16_019/0000759), Czech Grant Agency 20$07186 S$ to AK, JL, and VY: ERC CZ grant LL1601 to JL; Moravskoslezský Kraj research initiative grant RRC/10/2017 to JR; and a grant from Coordenação de Aperfeiçoamento de Pessoal de Nível Superior - Brasil (CAPES) - Finance Code 001, Conselho Nacional de Desenvolvimento Científico e Tecnológico (CNPq), Fundação de Amparo a Pesquisa do Estado do Rio de Janeiro (FAPE RJ) and Fundação Oswaldo Cruz (Fiocruz) to CMdAL.

\section{Availability of data and materials}

The sequences obtained in this study were submitted to GenBank and are available under accession numbers MT241902 - MT241904 (18S rRNA gene) and MT248930 - MT248932 (gGAPDH gene). The accession numbers of other sequences used in phylogenetic analyses are listed in the supplementary tables. Two datasets were placed to the Figshare depository: (i) for the analysis of the cell cycle [83] doi: https://doi.org/10.6084/m9. figshare.13154483 and (ii) for the motility analysis [84] doi: https://doi.org/10. 6084/m9.figshare.13154378.

Ethics approval and consent to participate

Not applicable.

\section{Consent for publication}

Not applicable.

\section{Competing interests}

The authors declare that they have no competing interests.

\section{Author details}

${ }^{1}$ Life Science Research Centre, Faculty of Science, University of Ostrava, Chittussiho 10, 71000 Ostrava, Czechia. ${ }^{2}$ Zoological Institute of the Russian Academy of Sciences, St. Petersburg 199034, Russia. ${ }^{3}$ Institute of Parasitology, Czech Academy of Sciences, 37005 České Budějovice, Czechia. ${ }^{4}$ Instituto Oswaldo Cruz, Fundação Oswaldo Cruz, Rio de Janeiro 21040-900, Brazil. ${ }^{5}$ Faculty of Sciences, University of South Bohemia, 37005 České Budějovice, Czechia. ${ }^{6}$ Martsinovsky Institute of Medical Parasitology, Sechenov University, Moscow 119435, Russia.

Received: 3 May 2020 Accepted: 4 November 2020

Published online: 02 December 2020

\section{References}

1. Podlipaev SA. Catalogue of world fauna of Trypanosomatidae (Protozoa), vol. 144. Leningrad: Zoologicheskii Institut AN SSSR; 1990. (In Russian).

2. Vickerman K. The diversity of the kinetoplastid flagellates. In: Biology of the Kinetoplastida. Edited by Lumsden WHR, Evans DA, vol. 1. London: Academic Press; 1976. p. 1-34.

3. Bruschi F, Gradoni L. The leishmaniases: old neglected tropical diseases. Cham: Springer; 2018.

4. Telleria J, Tibayrenc M. American trypanosomiasis Chagas disease : one hundred years of research. 2nd ed. Amsterdam: Elsevier; 2017.

5. Büscher P. Cecchi G, Jamonneau V Priotto G. Human African trypanosomiasis. Lancet. 2017;390(10110):2397-409.

6. Záhonová K, Kostygov AY, Ševčíková T, Yurchenko V, Eliáš M. An unprecedented non-canonical nuclear genetic code with all three 
termination codons reassigned as sense codons. Curr Biol. 2016;26(17): 2364-9.

7. Teixeira MM, Borghesan TC, Ferreira RC, Santos MA, Takata CS, Campaner M, Nunes VL, Milder RV, de Souza W, Camargo EP. Phylogenetic validation of the genera Angomonas and Strigomonas of trypanosomatids harboring bacterial endosymbionts with the description of new species of trypanosomatids and of proteobacterial symbionts. Protist. 2011;162(3):503-24.

8. Votýpka J, Kostygov AY, Kraeva N, Grybchuk-leremenko A, Tesařová M, Grybchuk D, Lukeš J, Yurchenko V. Kentomonas gen. n., a new genus of endosymbiont-containing trypanosomatids of Strigomonadinae subfam. n. Protist. 2014;165(6):825-38

9. Kostygov AY, Dobáková E, Grybchuk-leremenko A, Váhala D, Maslov DA, Votýpka J, Lukeš J, Yurchenko V. Novel trypanosomatid-bacterium association: evolution of endosymbiosis in action. mBio. 2016;7(2):e01985-15.

10. Grybchuk D, Kostygov AY, Macedo DH, Votýpka J, Lukeš J, Yurchenko V. RNA viruses in Blechomonas (Trypanosomatidae) and evolution of Leishmaniavirus. mBio. 2018;9(5):e01932-18.

11. Grybchuk D, Akopyants NS, Kostygov AY, Konovalovas A, Lye LF, Dobson DE, Zangger H, Fasel N, Butenko A, Frolov AO, et al. Viral discovery and diversity in trypanosomatid protozoa with a focus on relatives of the human parasite Leishmania. Proc Natl Acad Sci U S A. 2018;115(3):E506-15.

12. Hoare CA, Wallace FG. Developmental stages of trypanosomatid flagellates: a new terminology. Nature. 1966;212:1385-6.

13. Maslov DA, Votýpka J, Yurchenko V, Lukeš J. Diversity and phylogeny of insect trypanosomatids: all that is hidden shall be revealed. Trends Parasitol. 2013;29(1):43-52.

14. Maslov DA, Opperdoes FR, Kostygov AY, Hashimi H, Lukeš J, Yurchenko V. Recent advances in trypanosomatid research: genome organization, expression, metabolism, taxonomy and evolution. Parasitology. 2019;146(1):1-27.

15. Votýpka J, d'Avila-Levy CM, Grellier P, Maslov DA, Lukeš J, Yurchenko V. New approaches to systematics of Trypanosomatidae: criteria for taxonomic (re)description. Trends Parasitol. 2015;31(10):460-9.

16. Leidy J. A synopsis of entozoa and some of their ecto-congeners, observed by the author. Proc Acad Natl Sci Phila. 1856;8:42-58.

17. Wallace FG. The trypanosomatid parasites of insects and arachnids. Exp Parasitol. 1966;18(1):124-93.

18. Prowazek S. Die Entwicklung von Herpetomonas, einem mit den Trypanosomen verwandten Flagellaten. Arb Gesundh-Amte (Berl). 1904;20:440-52.

19. Patton WS, Strickland C. A critical review of the relation of blood-sucking invertebrates to the life cycles of the trypanosomes of vertebrates, with a note on the occurrence of a species of Crithidia, C. ctenopthalmi, in the alimentary tract of Ctenopthalmus agyrtes, Heller. Parasitology. 1908;1(4):322-46.

20. Patton WS. Inoculation of dogs with the parasite of kala azar (Herpetomonas [Leishmania] donovani) with some remarks on the genus Herpetomonas. Parasitology. 1908;1(4):311-3.

21. Porter A. The life-cycle of Herpetomonas jaculum (Léger), parasitic in the alimentary tract of Nepa cinerea. Parasitology. 1909;2(4):367-91.

22. Léger $L$. Sur la structure et le mode de multiplication des flagélles du genre Herpetomonas Kent. Comp R Séances Soc Biol. 1902;54(14):398-400.

23. Mackinnon DL. Herpetomonads from the alimentary tract of certain dungflies. Parasitology. 1910;3(3):255-74.

24. Woodcock HM. Further remarks on the flagellate parasites of Culex. Is there a generic type, Crithidia? Zool Anz. 1914;44(1):26-33.

25. Wenyon CM. Observations on Herpetomonas muscae-domesticae and some allied flagellates with special reference to the structure of their nuclei. Arch Protistenkd. 1913;31(1):1-36.

26. Rogers WE, Wallace FG. Two new subspecies of Herpetomonas muscarum (Leidy, 1856) Kent, 1880. J Protozool. 1971;18(4):645-54.

27. Brun R. Ultrastruktur und Zyklus von Herpetomonas muscarum, "Herpetomonas mirabilis" und Crithidia luciliae in Chrysomyia chloropyga. Acta Trop. 1974;31(3):219-90.

28. Wallace FG, Wagner M, Rogers WE. Varying kinetoplast ultrastructure in two subspecies of Herpetomonas muscarum (Leidy). J Protozool. 1973;20(2):218-22.

29. Borst P, Hoeijmakers JHJ, Hajduk SL. Structure, function and evolution of kinetoplast DNA. Parasitology. 1981;82(4):81-93.

30. Mallinson DJ, Lackie JM, Coombs GH. The oxidative response of rabbit peritoneal neutrophils to leishmanias and other trypanosomatids. Int J Parasitol. 1989;19(6):639-45.

31. Redman CA, Coombs GH. The products and pathways of glucose catabolism in Herpetomonas muscarum ingenoplastis and Herpetomonas muscarum muscarum. J Eukaryot Microbiol. 1997;44(1):46-51.
32. Vickerman K, Preston TM. Comparative cell biology of the kinetoplastid flagellates. In: WHR L, Evans DA, editors. Biology of Kinetoplastida, vol. 1. London: Academic Press; 1976. p. 35-130.

33. He CY, Singh A, Yurchenko V. Cell cycle-dependent flagellar disassembly in a firebug trypanosomatid Leptomonas pyrrhocoris. mBio. 2019;10(6):e02424-19.

34. Archibald JM. Handbook of the protists. New York: Springer Berlin Heidelberg; 2017.

35. Votýpka J, Klepetková H, Jirků M, Kment P, Lukeš J. Phylogenetic relationships of trypanosomatids parasitising true bugs (Insecta: Heteroptera) in sub-Saharan Africa. Int J Parasitol. 2012;42(5):489-500.

36. Chandler JA, James PM. Discovery of trypanosomatid parasites in globally distributed Drosophila species. Plos One. 2013;8(4):e61937.

37. Votýpka J, Pafco B, Modrý D, Mbohli D, Tagg N, Petrželková KJ. An unexpected diversity of trypanosomatids in fecal samples of great apes. Int J Parasitol Parasites Wildl. 2018;7(3):322-5.

38. Týč J, Votýpka J, Klepetková H, Šuláková H, Jirků M, Lukeš J. Growing diversity of trypanosomatid parasites of flies (Diptera: Brachcera): frequent cosmopolitism and moderate host specificity. Mol Phylogenet Evol. 2013;69: 255-64.

39. Votýpka J, Kment P, Kriegová E, Vermeij MJA, Keeling PJ, Yurchenko V, Lukeš J. High prevalence and endemism of trypanosomatids on a small Caribbean island. J Eukaryot Microbiol. 2019;66(4):600-7.

40. d'Avila-Levy CM, Boucinha C, Kostygov A, Santos HL, Morelli KA, Grybchukleremenko A, Duval L, Votýpka J, Yurchenko V, Grellier P, et al. Exploring the environmental diversity of kinetoplastid flagellates in the high-throughput DNA sequencing era. Mem Inst Oswaldo Cruz. 2015;110(8):956-65.

41. Frolov AO, Malysheva MN, Ganyukova Al, Spodareva W, Yurchenko V, Kostygov AY. Development of Phytomonas lipae sp. n. (Kinetoplastea: Trypanosomatidae) in the true bug Coreus marginatus (Heteroptera: Coreidae) and insights into the evolution of life cycles in the genus Phytomonas. Plos One. 2019;14(4):e0214484

42. Zídková L, Čepička I, Votýpka J, Svobodová M. Herpetomonas trimorpha sp. nov. (Trypanosomatidae, Kinetoplastida), a parasite of the biting midge Culicoides truncorum (Ceratopogonidae, Diptera). Int J Syst Evol Microbiol. 2010;60(Pt 9):2236-46.

43. Wilfert $L$, Longdon B, Ferreira AG, Bayer F, Jiggins FM. Typanosomatids are common and diverse parasites of Drosophila. Parasitology. 2011;138(7):858-65.

44. d'Avila-Levy CM, Bearzatto B, Ambroise J, Helaers R, Butenko A, Yurchenko V, Morelli KA, HLC S, Brouillard P, Grellier P, et al. First draft genome of the trypanosomatid Herpetomonas muscarum ingenoplastis through MinION Oxford Nanopore Technology and Illumina Sequencing. Trop Med Infect Dis. 2020;5(1):25.

45. Adl SM, Bass D, Lane CE, Lukes J, Schoch CL, Smirnov A, Agatha S, Berney C, Brown MW, Burki F, et al. Revisions to the classification, nomenclature, and diversity of eukaryotes. J Eukaryot Microbiol. 2019;66(1):4-119.

46. Bailey $\mathrm{CH}$, Brooks WM. Histological observations on larvae of the eye gnat Hippelates pusio (diptera: Chloropidae), infected with the flagellate Herpetomonas muscarum. J Invertebr Pathol. 1972;19(3):342-53.

47. Langousis G, Hill KL. Motility and more: the flagellum of Trypanosoma brucei. Nat Rev Microbiol. 2014;12(7):505-18.

48. Frolov AO, Malysheva MN, Kostygov AY. Transformations of life cycles in the evolutionary history of trypanosomatids: endotransformations and aberrations. Parazitologiia. 2016;50(2):97-113 (In Russian).

49. Frolov AO. Trypanosomatids (Kinetoplastea: Trypanosomatida) and insects (Insecta): patterns of co-evolution and diversification of the host-parasite systems. Proc Zool Inst RAS. 2016;320(S4):16-75 (In Russian).

50. Frolov AO, Skarlato SO. Fine structure and mechanisms of adaptation of lower trypanosomatids in Hemiptera. Tsitologyia. 1995;37(7):539-60 (In Russian).

51. Tieszen KL, Molyneux DH, Abdel-Hafez SK. Host-parasite relationships of Blastocrithidia familiaris in Lygaeus pandurus Scop. (Hemiptera: Lygaeidae). Parasitology. 1986;92(1):1-12.

52. Lauge $\mathrm{G}$, Nishioka RS. Ultrastructural study of the relations between Leptomonas oncopelti (Noguchi and Tilden), Protozoa Trypanosomatidae, and the rectal wall of adults of Oncopeltus fasciatus Dallas, Hemiptera Lygaeidae. J Morphol. 1977;154(2):291-305.

53. Molyneux DH, Croft SL, Lavin DR. Studies on the host-parasite relationships of Leptomonas species (Protozoa: Kinetoplastida) of Siphonaptera. J Natl Hist. 1981;15(3):395-406.

54. Tieszen KL, Molyneux DH, Abdelhafez SK. Host-parasite relationships and cysts of Leptomonas lygaei (Trypanosomatidae) in Lygaeus pandurus (Hemiptera, Lygaeidae). Parasitology. 1989;98:395-400. 
55. Skalický $T$, Dobáková E, Wheeler RJ, Tesařová M, Flegontov $P$, Jirsová $D$, Votýpka J, Yurchenko V, Ayala FJ, Lukeš J. Extensive flagellar remodeling during the complex life cycle of Paratrypanosoma, an early-branching trypanosomatid. Proc Natl Acad Sci U S A. 2017;114(44):11757-62.

56. Vickerman K, Tetley L. Flagellar surfaces of parasitic protozoa and their role in attachment. In: Bloodgood RA, editor. Ciliary and Flagellar Membranes. Boston: Springer; 1990. p. 267-304.

57. Frolov AO, Malysheva MN, Ganyukova Al, Yurchenko V, Kostygov AY. Life cycle of Blastocrithidia papi sp. n. (Kinetoplastea, Trypanosomatidae) in Pyrrhocoris apterus (Hemiptera, Pyrrhocoridae). Eur J Protistol. 2017;57:85-98.

58. Frolov AO, Malysheva MN, Ganyukova Al, Spodareva W, Králová J, Yurchenko V, Kostygov AY. If host is refractory, insistent parasite goes berserk: Trypanosomatid Blastocrithidia raabei in the dock bug Coreus marginatus. Plos One. 2020;15(1):e0227832.

59. Terra WR. The origin and functions of the insect peritrophic membrane and peritrophic gel. Arch Insect Biochem Physiol. 2001;47(2):47-61.

60. Peters W. Peritrophic membranes. Berlin: Springer-Verlag; 1992.

61. Dostálová A, Volf P. Leishmania development in sand flies: parasite-vector interactions overview. Parasit Vectors. 2012;5:276.

62. Sádlová J, Volf P. Peritrophic matrix of Phlebotomus duboscai and its kinetics during Leishmania major development. Cell Tissue Res. 2009;337(2):313-25.

63. Wheeler RJ, Scheumann N, Wickstead B, Gull K, Vaughan S. Cytokinesis in Trypanosoma brucei differs between bloodstream and tsetse trypomastigote forms: implications for microtubule-based morphogenesis and mutant analysis. Mol Microbiol. 2013;90(6):1339-55.

64. Moreira-Leite FF, Sherwin T, Kohl L, Gull K. A trypanosome structure involved in transmitting cytoplasmic information during cell division. Science. 2001;294(5542):610-2.

65. Briggs LJ, McKean PG, Baines A, Moreira-Leite F, Davidge J, Vaughan S, Gull K. The flagella connector of Trypanosoma brucei: an unusual mobile transmembrane junction. J Cell Sci. 2004;117(Pt 9):1641-51.

66. Frolov AO, Malysheva MN, Yurchenko V, Kostygov AY. Back to monoxeny: Phytomonas nordicus descended from dixenous plant parasites. Eur J Protistol. 2016:52:1-10.

67. Schindelin J, Arganda-Carreras I, Frise E, Kaynig V, Longair M, Pietzsch T, Preibisch S, Rueden C, Saalfeld S, Schmid B, et al. Fiji: an open-source platform for biological-image analysis. Nat Methods. 2012;9(7):676-82.

68. Frolov AO, Malysheva MN, Ganyukova Al, Yurchenko V, Kostygov AY. Obligate development of Blastocrithidia papi (Trypanosomatidae) in the Malpighian tubules of Pyrrhocoris apterus (Hemiptera) and coordination of host-parasite life cycles. Plos One. 2018;13(9):e0204467.

69. Yurchenko V, Votýpka J, Tesařová M, Klepetková H, Kraeva N, Jirků M, Lukeš J. Ultrastructure and molecular phylogeny of four new species of monoxenous trypanosomatids from flies (Diptera: Brachycera) with redefinition of the genus Wallaceina. Folia Parasitol. 2014;61(2):97-112.

70. Maslov DA, Lukeš J, Jirků M, Simpson L. Phylogeny of trypanosomes as inferred from the small and large subunit rRNAs: implications for the evolution of parasitism in the trypanosomatid protozoa. Mol Biochem Parasitol. 1996:75(2):197-205.

71. Maslov DA, Yurchenko WY, Jirků M, Lukeš J. Two new species of trypanosomatid parasites isolated from Heteroptera in Costa Rica. J Eukaryot Microbiol. 2010;57(2):177-88.

72. Katoh K, Standley DM. MAFFT multiple sequence alignment software version 7: improvements in performance and usability. Mol Biol Evol. 2013 30(4):772-80.

73. Castresana J. Selection of conserved blocks from multiple alignments for their use in phylogenetic analysis. Mol Biol Evol. 2000;17(4):540-52.

74. Chistyakova LV, Kostygov AY, Kornilova OA, Yurchenko V. Reisolation and redescription of Balantidium duodeni Stein, 1867 (Litostomatea, Trichostomatia). Parasitol Res. 2014;113(11):4207-15.

75. Nguyen LT, Schmidt HA, von Haeseler A, Minh BQ. IQ-TREE: a fast and effective stochastic algorithm for estimating maximum-likelihood phylogenies. Mol Biol Evol. 2015;32(1):268-74.

76. Kalyaanamoorthy S, Minh BQ, Wong TKF, von Haeseler A, Jermiin LS ModelFinder: fast model selection for accurate phylogenetic estimates. Nat Methods. 2017;14(6):587-9.

77. Ronquist F, Teslenko M, van der Mark P, Ayres DL, Darling A, Hohna S, Larget B, Liu L, Suchard MA, Huelsenbeck JP. MrBayes 3.2: efficient Bayesian phylogenetic inference and model choice across a large model space. Syst Biol. 2012;61(3):539-42.
78. Emms DM, Kelly S. OrthoFinder: solving fundamental biases in whole genome comparisons dramatically improves orthogroup inference accuracy. Genome Biol. 2015;16:157.

79. Edgar RC. MUSCLE: multiple sequence alignment with high accuracy and high throughput. Nucleic Acids Res. 2004;32(5):1792-7.

80. Capella-Gutierrez S, Silla-Martinez JM, Gabaldon T. trimAl: a tool for automated alignment trimming in large-scale phylogenetic analyses. Bioinformatics. 2009;25(15):1972-3.

81. Wang HC, Minh BQ, Susko E, Roger AJ. Modeling site heterogeneity with posterior mean site frequency profiles accelerates accurate phylogenomic estimation. Syst Biol. 2018:67(2):216-35.

82. Lartillot N, Rodrigue N, Stubbs D, Richer J. PhyloBayes MPI: phylogenetic reconstruction with infinite mixtures of profiles in a parallel environment. Syst Biol. 2013;62(4):611-5.

83. Kostygov AY, Frolov AO, Malysheva MN, Ganyukova Al, Chistyakova LV, Tashyreva D, Tesařová M, Spodareva W, Režnarová J, Macedo DHF et al: Cell cycle analysis dataset for Vickermania. 2020. Figshare doi: https://doi.org/10. 6084/m9.figshare.13154483.

84. Kostygov AY, Frolov AO, Malysheva MN, Ganyukova Al, Chistyakova LV, Tashyreva D, Tesařová M, Spodareva W, Režnarová J, Macedo DHF et al: Motility analysis dataset for Vickermania. 2020. Figshare doi: https://doi.org/ 10.6084/m9.figshare.13154378.

\section{Publisher's Note}

Springer Nature remains neutral with regard to jurisdictional claims in published maps and institutional affiliations.
Ready to submit your research? Choose BMC and benefit from:

- fast, convenient online submission

- thorough peer review by experienced researchers in your field

- rapid publication on acceptance

- support for research data, including large and complex data types

- gold Open Access which fosters wider collaboration and increased citations

- maximum visibility for your research: over $100 \mathrm{M}$ website views per year

At BMC, research is always in progress.

Learn more biomedcentral.com/submissions 